

\section{HISTORICAL HOUSEHOLD BUDGETS \\ WORKING PAPER SERIES}

HHB working papers are circulated for discussion purposes. They have not been peer-reviewed by external referees or been subject to the review by the HHB Advisory Board.

You can copy, download or print HHB content for your own use, and you may include excerpts from HHB publications, databases and multimedia products in your own documents, presentations, blogs, websites and teaching materials, provided that suitable acknowledgment of HHB as source and copyright owner is given. All requests for commercial use and translation rights should be submitted to info@hhbproject.com.

Comments are welcome and may be sent to info@hhbproject.com.

Please cite this paper as:

Chianese, S. (2016), 'The baraccati of Rome: internal migration, housing, and poverty in fascist Italy (1924-1933)', HHB Working Paper Series, No. 6, November 2016, Rome.

(C) 2016 Historical Household Budgets

HHB Project Via Columbia, 2

00133 Rome

Italy

http://hhbproject.com/

All rights reserved. Short sections of text, not to exceed two paragraphs, may be quoted without explicit permission provided that full credit is given to the source. 


\title{
The baraccati of Rome: internal migration, housing, and poverty in fascist Italy (1924-1933) ${ }^{1}$
}

\author{
Stefano Chianese \\ University of Rome "Tor Vergata"
}

November 2016

\begin{abstract}
Newly discovered archival material is used to document the standard of living of slum dwellers in fascist Rome. As part of the regime's effort to suppress growing shanty towns in the capital, the Governorate of Rome conducted a census in 1933, gathering information on the identity and living conditions of their inhabitants, the "baraccati". The paper analyzes the mostly migrant families of the shanty towns, identifying their social and demographic characteristics.
\end{abstract}

Keywords: Housing; internal migration; poverty; slum dwellers; fascism.

JEL classification : N01, N03, N09, R23, R03

\footnotetext{
${ }^{1}$ I thank for their useful and thoughtful comments Brian A' Hearn, Nicola Amendola, Giovanni Federico, Alessandro Nuvolari, Giovanni Vecchi and the HHB team (http://hhbproject.com).
} 


\section{Introduction}

On Thursday, 24 March, 2016, in the Campidoglio council chamber, in the middle of the campaign for the election of the new mayor of Rome and before many of the candidates, the Associazione 21 luglio presented a dossier pointedly titled 'Rome: beyond the slum settlements: A political agenda for the renewal of the abandoned suburbs'. The dossier calls attention to a phenomenon that is deeply entrenched in the city's history. Today's slum settlements are inhabited mostly by Rom and Sinti communities, although the economic crisis has also driven many Italians back there. In the past, these slum areas gave refuge to pockets of poverty, people excluded from the unaffordable property market and tightly packed social housing. Historians, sociologists and social scientists continue to study the phenomenon with interest. ${ }^{2}$ Yet the evidence that has contributed most to building our shared historical memory comes chiefly from film and literature. Pier Paolo Pasolini's novel Ragazzi di vita, Vittorio De Sica's film The Roof and Ettore Scola's film Down and Dirty are just a few of the masterpieces that captured, in varying shades and nuances, the life of the Roman baraccati.

Rome's slums multiplied during the periods in which immigration, poverty and the housing crisis coalesced: 'After the crisis of 1887 - and the cessation of building activity that followed, and which lasted almost twenty years while massive immigration continued to take place - the suburban districts began to form, rapidly expanding into gigantic sprawls' (Berlinguer and Della Seta 1960). The first official data are provided by the 1911 census: 8,975 irregular dwellings were recorded, i.e. underground, ground-floor, in attics and workshops, as well as more than 2,915 unfit dwellings consisting of shacks, sheds and huts. Moreover, the special survey of housing carried out in 1931 recorded 2,911 shacks in Rome. In 1957, the city council ordered a survey of insecure dwellings and their resident population. The findings brought to light a troubling situation: 13,131 dwellings occupied by 13,703 households consisting of a total of 54,576 people, or $3.75 \%$ of Rome's resident population (Salvucci 2014). The phenomenon is clearly a constant in the city's

\footnotetext{
${ }^{2}$ Most research on the slum settlements takes the mid-20 $0^{\text {th }}$-century as the starting point for studying the phenomenon. See Bonomo (2003), Perego and Clementi (1983), Berlinguer and Della Seta (1976), Ferrarotti (1974) and D’Apice and Mazzetti (1970).
} 
history, and it tends to swell when population growth and increased poverty create new housing crises.

There is a moment in Italy's history - and that of its capital - when the three elements at the root of the spread of the slum settlements became magnified. Between World War I and World War II, at the height of Fascism, droves of Italians abandoned the countryside and small villages to converge on the big cities of the centre and north of the country. For a long time it was believed that during the twenty years of Fascism population movements in Italy crystallized. This conviction has been completely overturned by major studies, particularly in the fields of demographic and social history (Treves 1976; Bevilacqua, De Clementi and Franzina 2001; Gallo 2012). Yet, little is known still about the huge migrations that crossed the country between the two wars. The city most affected was Rome. In the space of barely fifteen years, from the 1921 census to that of 1936 , the capital grew from 660,000 to over $1,100,000$ inhabitants, an increase of $74 \%$, most of it due to immigration. Rome was largely unprepared to cope with such a demographic boom.

The migration flow inevitably affected the local housing market and compounded the existing phenomenon of illegal slum settlements. Previously unpublished documentation found in Rome's Capitoline Archives provides us with a very detailed view of the dual phenomenon of internal immigration and spontaneous slum settlements in Rome during Fascism. ${ }^{3}$ The UAS (Ufficio Assistenza Sociale_-"Social Assistance Office") of the Governorate, ${ }^{4}$ Rome's local government body, was directly responsible for the matter of the settlements, a task it shared with the Questura (police headquarters) and the EACP (Ente Autonomo Case Popolari- "Social Housing Agency"). The documents of the UAS describe the strategies adopted to limit the phenomenon, but they also allow us a view of who the Roman slum dwellers were during Fascism. From 1924 to 1933, the Governorate carried out several censuses to monitor the situation. The newly available documentation has brought to light not only data summarizing those surveys but also individual household files from the last census, dated 1933. These are the census forms of 4,405

\footnotetext{
${ }^{3}$ We wish to thank all the staff of the Capitoline Historical Archives for their indispensable support during our research, and especially Ms Gori, whose efforts to reorganize the fond of the Social Assistance Office have provided the scientific community with some extremely important historical documentation that was previously not known to exist.

${ }^{4}$ On the social security policies of the Governorate see Santori (1984)
} 
households, comprising a total of 19,218 individuals. The huge range of information provided makes up the main data set on which this article is based.

The paper is organized as follows. In Section 2 and 3, after a brief description of the sources and their origins, I outline the policies adopted by the Governorate to stop the development of the slum settlements. In Section 4, 5 and 6, I describe the social and economic profile of Roman slum dwellers. The concluding sections 7 and 8 contain a brief description of general internal mobility during Fascism, after which I analyse the specific characteristics of the migrants crowding the slums of the capital.

\section{The archives of the Social Assistance Office and the census of the slum dwellers}

The increase in the population created problems for the housing market, which was unable to absorb such a large number of new town dwellers. The literature dealing with contemporary migration trends has also highlighted the effects on the housing market of the massive movements of migrants to the towns (Cannari, Nucci and Sestito 2000; Saiz 2003; Gonzales and Ortega 2009; Whitehead et al. 2011; Kalantaryan 2013). But there were other factors that contributed to changing living conditions in the capital city. First, the liberalization of the rental market, the result of a series of measures culminating in Law 1155/1928, contributed to a rise in house prices. ${ }^{5}$ Another factor was the profound transformation of the urban structure of the city due to the sventramento (gutting) of the historic centre, which provoked the movement of a section of the working classes towards the outskirts. ${ }^{6}$ The evicted Romans and migrants therefore found themselves competing for homes in the complex and costly property market of the capital city. Figure 1 illustrates the enormous difference in the cost of homes in Rome compared with the other main Italian cities. $^{7}$

\footnotetext{
${ }^{5}$ The government's policy on rent regulation fluctuated as it constantly had to balance the need to keep rental costs down and the need for new private investment in the construction sector, fostered by the greater liberalization of rents. Decree 8/1923 had already effected a partial liberalization of market prices; later Law $948 / 1927$ enacted a return to a system of partial restrictions which was then finally repealed by Law $1155 / 1928$.

${ }^{6}$ The term sventramenti covered a series of interventions that profoundly changed the ancient centre of Rome. The vast literature on the history, architecture and town planning of Rome heavily criticized the quality and usefulness of the work carried out in those years, see Cederna $(1956,1965,1979)$, Insolera (1962, 2001) and Insolera and Perego (1999).

${ }^{7}$ On house price trends in Italy, see also Cannari, D’Alessio and Vecchi (2016).
} 
Figure 1: Annual rents per room in the main Italian cities (1927-1930)

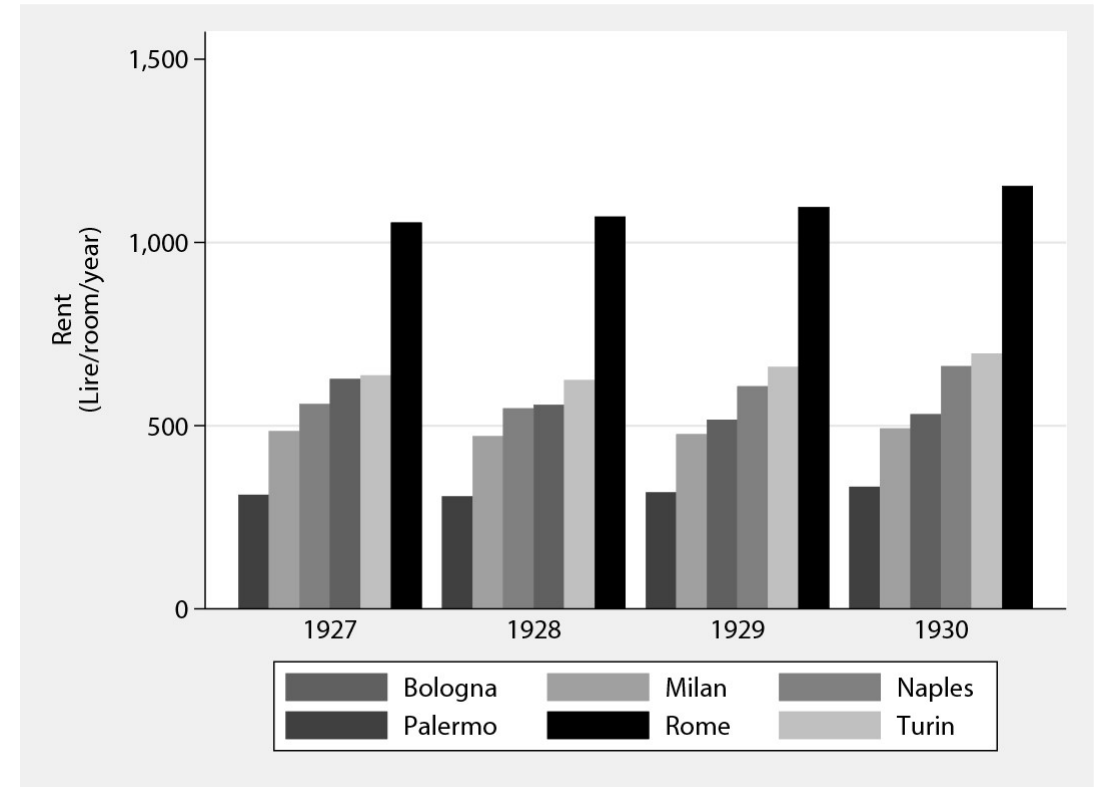

Source: Istat (1931)

Such a highly priced housing market made Rome even less welcoming to the inflow of migrants, against whom the regime raised powerful, but ineffective, legislative barriers. ${ }^{8}$ In this very difficult context, one of the spontaneous responses of both new town dwellers and the native Romans who had to address housing problems was to construct their own makeshift accommodation. So it was that in various areas of the city clusters of slum dwellings multiplied and for years provided shelter to tens of thousands of people. It fell to the welfare institutions to directly address the city's demographic and housing crisis. In particular, the Governorate's Social Assistance Office found itself in the front line dealing with an increasing demand for new social housing. The Governorate was the capital's local government body and its social welfare office covered a broad range of functions, from combating begging to the prevention of TB, from welfare at school to maternity assistance (Salvatori 2006). The most important of its functions was indeed the

\footnotetext{
${ }^{8}$ The Fascist policy against internal mobility and migration to the towns began after Mussolini's famous Ascension speech of 1927. On that occasion the Duce outlined the population policy guidelines of the regime, describing industrial urbanization as a 'destructive factor that sterilizes the population'. The first law passed to limit internal mobility within the country was Law 2961/1928, which gave Prefects the power to issue orders to limit the inflow of migrants into the urban centres. A second piece of legislation followed, Law 358/1931, which established a 'Commission for migration and internal colonization' to centralize flow control. Lastly, in 1939, Law 1092/1939 was passed banning anyone from migrating to an urban centre without a signed employment contract in the destination town.
} 
management of social housing, a competence shared, though often competitively, with the Fascist Social Housing Institute (Istituto Case Popolari Fascista) (Villani 2012).

As part of its policy to control the spread of the slum settlements, on at least four occasions (1924, 1927, 1929 and 1933) the Governorate of Rome made surveys, of varying degrees of detail, to monitor the phenomenon. The survey forms called for a wide range of information. For each household member it was necessary to specify age, occupation, place of work, income and, for children, school attendance. As regards the head of household, besides the above information, we also know place of birth, year of arrival in Rome, previous place of residence and the number of years spent living in a slum settlement. Lastly, the census produced other very useful information on various aspects of households and dwellings: number of rooms, construction materials, and the reasons for leaving the previous dwelling. The census results were not made public. News of the census being carried out could be found in Capitolium, the Governorate's own periodical, which published a brief article in 1930, written by the head of the UAS at the time, Raffaello Ricci, giving some very superficial information on the 1929 census (Ricci 1930).

In the next section, I will try to describe the main policies put in place by the Governorate to counter the phenomenon.

\section{The Governorate's battle against the illegal slum settlements}

The UAS slum-settlement archival collection is a treasure trove of information on the phenomenon and on the methods used to combat it. The Governorate took action along three main policy lines. First, it closely monitored the territory to prevent new slum settlements forming; next, it sought to repatriate immigrant households; and third, it tried to create forms of social housing destined for former slum dwellers. As we will see, these measures were not enough to solve the problem. To monitor the territory, in 1925 the Governorate set up a special team within the Ufficio Edilizio (Construction Office), tasked with finding and demolishing any settlements under construction. However, the effectiveness of the Governorate's policy of control and repression was hampered by economic and logistic difficulties. The head of the building department wrote, on 28 
August 1925, that 'almost invariably, orderly demolition proves impossible because the dwellings are still occupied by old or sick people'. ${ }^{9}$

Repatriations were ordered in cases of extreme poverty and, though much less often, of social dangerousness. The households selected for repatriation were mainly those whose senior member was a widow or a woman separated from her husband, or again a sick or disabled person or person unable to procure even subsistence-level income. Such households were offered a small sum or a refund of part of their travel costs to return to their place of origin. As for social housing, the homes that would be allocated basically fell into two categories: they were either extremely cheap homes, built not unlike the very slum dwellings the people were forced to leave, or so-called suburban hostels. Between 1925 and 1927 some 920 dwellings were built and assigned to households of baraccati (Villani 2012), far too few to stanch the emergency and of such abysmal quality that they did little or nothing to improve the housing standards of their occupants. Even worse was the situation in the suburban hostels. 'They were conceived in order to create a "large breathing space" for the hundreds of families evicted from their provisional homes (...). The furnishings were mass-produced and the occupants' few odds and ends were sterilized and stored in warehouses to be returned to them at the end of their stay, making eviction easier. The rent for accommodation in the hostels was paid fortnightly and was extremely high to discourage the occupants from lingering. It was forbidden to eat in the rooms and meals were taken in a large communal dining room. Food was prepared in a big central kitchen and paid for with compulsory ration cards that increased the cost of the stay' (Villani 2012).

It was a social housing project that was emblematic of the regime's approach to the problem. Rather than find permanent housing solutions, the authorities sought to keep the problem at bay while making life difficult for the immigrants in the hope that they would go home of their own free will. A letter written by Mussolini in 1933 to the Governor Boncompagni Ludovisi perfectly summarizes the policies of the Governorate: 'efforts so far to combat the development of slum settlements have not produced satisfactory results. We need to change our approach and tackle the problem as a whole and with firmness. To raze a slum, first raise a slum. In my opinion we need to: build simultaneously five settlements, at a convenient distance, with only the foundations in cement; gather up all

\footnotetext{
${ }^{9}$ Archivio storico capitolino, Ufficio assistenza sociale, Baraccati Busta 102 fascicolo 2.
} 
the slum dwellers and move them there, after examining individual cases in order to send as many families as possible back to their place of origin; create a police force of 10-12 agents to seek out any new attempt, be it individual or collective, to build slum dwellings and immediately pull down anything that has been started' ${ }^{10}$ The letter, along with all the other evidence found in the Capitoline Archives' collection, confirms that the Duce himself took an interest in the matter. Indeed, the regime had made anti-urbanization a linchpin of its strategy and the slum settlements were a moveable demonstration of the contradiction between the regime's propaganda and reality.

The sources also reveal that the local authorities knew that the situation was particularly favourable for the spread of settlements. Increasing immigration and excessively high house prices were the issues most often cited. To give an example, a memo written by the general accounts office of the Governorate in 1924 states that 'the building of slum settlements is not a sporadic or intermittent phenomenon. In a city of such intense urbanization as Rome, lying at the centre of vast expanses of countryside where the population lives a primitive way of life in primitive accommodation, the building of slum dwellings is deeply rooted in the activity of every family'. ${ }^{11}$ Governor Cremonini, in a letter to the Questura dated 1926, points the finger at the high cost of housing: 'However, we have reason to believe that when the many evictions take place - to be notified shortly, when the measures abolishing the system of rent controls come into effect - numerous attempts will be made to build slum dwellings' ${ }^{12}$

Although the Governorate was aware of the problem it appeared helpless before the haphazard dynamics governing the unlawful division of State and private land into lots. A letter signed by a group of 29 families of slum dwellers on 10 October 1924 sheds light on some of these dynamics: 'All the petitioners being homeless (...) they discovered in Via Portuense a piece of land large enough to build dwellings to live in. This land belonging to the State had been let to one Giovanni Antilici for use as pasture land only, and when the undersigned applied to him he in turn sublet the land to build dwellings, receiving in return thirty lire a month for each shack (...). The land was in no way unlawfully occupied, but only with the agreement of said person' ${ }^{13}$

\footnotetext{
${ }^{10}$ Archivio storico capitolino, Ufficio assistenza sociale, Baraccati Busta 102 fascicolo 1.

${ }^{11}$ Archivio storico capitolino, Ufficio assistenza sociale, Baraccati Busta 91 fascicolo 1.

${ }^{12}$ Archivio storico capitolino, Ufficio assistenza sociale, Baraccati Busta 91 fascicolo 1.

${ }^{13}$ Archivio storico capitolino, Ufficio assistenza sociale, Baraccati Busta 92 fascicolo 2.
} 
The UAS's Archive is full of documents that tell this kind of story in various ways and for various reasons. Basically, partly because of the plentiful empty land, both private and State-owned - which has always been a characteristic of Rome - a fully-fledged informal market came into being for land that was rapidly converted into slum settlements. It thus became very difficult to control the phenomenon, and the Governorate's attempts to carry out a census of the slum dwellers should be viewed in this light. The information deduced from the censuses allows us to partially reconstruct the phenomenon over a period of about 10 years, which are summarized in the following section.

\section{Census results 1924-1933}

The first question to address before going into the findings is how the term baracca (shack) was defined in the Governorate's census. Unfortunately, no clear definition was given in the survey. On the other hand, there is an indirect element that allows us to reconstruct a partial definition. As already underlined, one of the objectives of the census was to pinpoint the slum settlements in order to proceed to the successive demolition of unlawful constructions. The piece of legislation that made it possible to demolish the shacks was Article 1 of the municipal and provincial law of 1915 giving the mayor the power 'to take unforeseen and urgent measures' in the field of construction and public safety. Basically, the constructions that could be defined unlawful were all those that did not comply with the public health and safety criteria dictated by law. This was, of course, a very imprecise definition but it provided the Governorate with a plausible legislative pretext for going ahead with the demolitions.

After defining the subject of the survey, albeit indirectly, we can now analyse the results. Unfortunately, not much information was published and there is very little summary data to be found in the archive material.

Moreover, it is not possible to ascertain how far the various findings are effectively comparable and whether they can provide an accurate picture of the overall situation. There is very little information on the methodologies used and the degree of coverage of the different surveys. We will try in any case to take stock of what we are able to reconstruct. 
An initial, extremely brief, survey dates back to 1924. In this case we are only told the zones where slum settlements appeared, the number of dwellings and the total number of inhabitants. The 2,825 dwellings surveyed housed a population of 16,259 people, with an average of just under six people per unit. Given that the most usual type of dwelling comprised one communal room and a second one used as a kitchen and, in particularly fortunate cases, a toilet, the overcrowding and lack of privacy were very evident.

Some more information can be gleaned from the second census carried out in 1927. In this case the shacks housed 4,884 families, made up of 19,660 individuals in total. Besides the size of the sample, the 1927 census also provides us with the origin of the slum dwellers. As we will see below when examining the 1933 census forms in detail, the slum dwellers mainly came from the Lazio region and the province of Rome in particular. Table 1 summarizes the regions and main provinces of origin of the slum dwellers in 1927. The results are partially inaccurate because the places of origin were recorded without subtracting the natives from the total for Lazio and the province of Rome and therefore the figure was overestimated. Despite this, two findings emerged: 1) the prevalence of short-range immigration and 2) the direction of the migration movements was from east to west rather than from north to south.

Table 1: Regions and provinces of origin of the slum dwellers surveyed in the 1927 census

\begin{tabular}{ccccc}
\hline Regions 1927 & $\%$ & & Provinces 1927 & $\%$ \\
\cline { 1 - 2 } Lazio & 47.7 & & Rome & 38 \\
Puglia & 13 & & Bari & 10 \\
Marche & 9.3 & & L’Aquila & 5 \\
Abruzzo & 6.3 & & Frosinone & 4.5 \\
Umbria & 4.4 & & Rieti & 3.7 \\
Emilia-Romagna & 3.3 & & Perugia & 3 \\
Campania & 2.4 & & Pesaro-Urbino & 3 \\
Sardinia & 2.2 & & Foggia & 2.8 \\
Others & 11.4 & & Others & 30 \\
\hline
\end{tabular}

Source: Based on data from Archivio Storico Capitolino, Ufficio Assistenza Sociale, Fondo Baraccati, busta 90. 
The other information to emerge from the 1927 census was the distribution of the slum settlements across the city: there were at least 156 conglomerations of very different sizes and concentration. The largest settlements were situated on the outskirts of the city but some had reached the heart of the historical centre: in the very central Via dei Cerchi, for example, only a stone's throw from the Campidoglio, there were at least 87 dwellings, with 67 households living in them.

The 1929 census data allow us to analyse the phenomenon from a different point of view. In fact, although there is no information about the places of origin of the slum dwellers, it is possible to know the occupation of the heads of household and, in summary, something about their income.

For the 1929 census it was decided to broaden the geographical reach of the survey to the outmost bounds of the twelve Roman suburbs. ${ }^{14}$ Inevitably, it was found that there had been a significant increase in the number of shacks and the number of inhabitants totalled 31,937 .

Excluding the previously mentioned difficulties in comparing the four censuses, we will try to analyse the overall data that emerge. Table 2 gives the number of households and individuals surveyed.

Table 2: Number of households and individuals living in slum settlements according to the Governorate's surveys

\begin{tabular}{ccc}
\hline Year & Households & Individuals \\
\hline 1924 & - & 16259 \\
1927 & 4884 & 19660 \\
1929 & 7716 & 31937 \\
1933 & 4405 & 19219 \\
\hline
\end{tabular}

Source: Based on data from ASC, Social Assistance Office and Fondo Baraccati.

\footnotetext{
${ }^{14}$ Urban Rome was divided into three levels: there were 22 rioni (neighbourhoods) making up the ancient centre of the city within the Aurelian walls; 15 quarters outside the walls; and 12 suburbs. Beyond the suburbs was the area called the agro-romano, the countryside surrounding the urban area of the capital city.
} 
Excluding the 1929 census, which had a broader reach, the data seem fairly stable. In 1933, almost ten years after the first monitoring exercise, the overall situation did not look any better and there had been an increase of around $18 \%$ in terms of number of residents. This would seem to confirm the ineffectiveness of the Governorate's prevention policies. The 1929 census was also commented on by the Director of the UAS, Raffaello Ricci, in the previously cited article published in 1930. He naturally adopted a propagandist tone: 'If the phenomenon of slum settlements is common to all large cities in Europe, perhaps in none of them has it been dealt with more vigorously in order to eliminate it than in Rome' (Ricci 1930). Behind the strong tones of propaganda, it is also possible to find some important pieces of information on the distribution of the settlements within the city, classified in terms of their distance from the city centre: 'it was noted that $3 / 5$ of the shacks were to be found in the band between the walls and a radius of $3 \mathrm{~km}$; more than $1 / 5$ were further than $3 \mathrm{~km}$ from the centre; and fewer than 1/5 inside the old walls' (Ricci 1930).

Ricci underestimated this aspect, but it is strange to think that even within the Aurelian walls, the boundary lines of the historical centre of the capital city, there were around 1,400 households of slum dwellers. The last piece of information contained in Ricci's article was about the jobs of the slum dwellers, which I present in Table 3.

Table 3: Employment status of the slum dwellers according to the 1929 census

\begin{tabular}{lc}
\hline Employment status & $\%$ \\
\hline Unskilled workers & 32.1 \\
Skilled workers & 15.4 \\
Construction workers & 11.6 \\
Public sector employees & 9 \\
Drivers & 7 \\
Housewives & 6.6 \\
Unemployed & 5.3 \\
Labourers & 3.7 \\
Traders & 3 \\
Farmers & 2 \\
Private sector employees & 0.7 \\
Craft workers & 0.6 \\
Others & 3 \\
\hline
\end{tabular}

Source: Ricci (1930). 
Ricci's classification of types of employment is very approximate and does not leave sufficient space for a proper analysis. Naturally, the traditional job categories for a group of immigrants that had been 'negatively' selected are well represented. See, for example, the high percentage of unskilled workers who, added to the category of construction workers, another low-skilled sector, account for almost half the entire sample. However, there are also some unexpected results that Ricci himself drew attention to: 'about another $12 \%$ work for public and private entities. Bearing in mind the abovementioned categories and others too, we may infer a result of notable political and social importance, i.e. that the slum dwellers are not all of a low social class, in the worst sense of the term' (Ricci 1930).

Another piece of information to come from the 1929 census is on slum dweller household income. The available information is the result of a short study made at the behest of the Social Assistance Office by Lanfranco Maroi, ${ }^{15}$ the Governorate's Director of Statistics at the time: 'We think that the household head's (daily) income cannot exceed on average 16 lire, which could rise to 19 lire if we take account of the income of other family members. This would give a monthly income of 570 lire out of which, taking account of the various categories of expenditure, only 70 or 80 lire at the most could be devoted to expenditure on housing'. ${ }^{16}$

Maroi himself, in a second document, provides a means of comparison that allows us to use the abovementioned information more analytically. On the basis of the wages of the various categories of workers and the cost of living in Rome, Maroi reconstructed the average budget of a working class family, composed of father, mother and three children aged under 11 years. In lire, earnings would be around 900 a month, which would have to cover weekly spending divided as follows: 144.72 for food, 25 for clothing, 12 for electricity and gas and 15 for miscellaneous personal items. This gave a weekly total of 196.72 and a monthly one of about 788, excluding housing costs. The difference was significant: a family of slum dwellers would have an income that was $40 \%$ lower than that of a working class family. ${ }^{17}$ The two data sets are of course difficult to compare but they have an indicative value. We can also attempt to compare the average income levels of

\footnotetext{
${ }^{15}$ Lanfranco Maroi (Avellino 1889 - Rome 1974), a leading Italian statistician, was President of the Italian National Statistics Institute (Istat) from 1949 to 1961.

${ }^{16}$ Archivio storico capitolino, Ufficio assistenza sociale, Baraccati Busta 90 fascicolo 2.

${ }^{17}$ Archivio storico capitolino, Ufficio assistenza sociale, Baraccati Busta 90 fascicolo 2.
} 
slum dwellers with the cost of living calculated by Maroi. In this case, excluding the cost of housing, which should be well below normal market values, the difference between the monthly income of slum dwellers and the average expenditure of a working class family was about $28 \%$.

In the absence of household census forms, it has not been possible to construct any other hypotheses from the censuses conducted prior to 1933. Instead, the last of the surveys provides us with many variables and checks that we can use. So, who were the Roman slum dwellers? Where did they come from? What work did they do? What were their living conditions? I will now try to answer these questions by tracing a socio-economic profile of the slum dwellers, based on the 1933 census forms.

\section{The 1933 census: a socio-demographic profile of the baraccati}

The census forms relate to 4,405 households, comprising a total of 19,218 individuals. In 1933, Rome had a population of around 1 million and therefore about $2 \%$ of the capital's inhabitants were surveyed. Of course, as the sample was not statistically selected it was not broadly representative; however, it is still worth seeing whether we can identify some typical features of a given section of the population (the poorest or immigrants, for example). It is impossible to assess accurately how far the census captured the phenomenon. In all likelihood, the number of baraccati was underestimated, first, because the phenomenon was in constant evolution and, second, because the baraccati were doubly vulnerable - as illegal slum dwellers and as undesirable immigrants - and so many of them may have tried to avoid being monitored. It is important, therefore, to understand how the census was carried out. The sources offer regrettably little information, but the methods were probably very similar to those described by Raffaello Ricci in his article on the 1929 census mentioned earlier: 'It was conducted by means a form that contained all the necessary information about the structure of the household, the profession of the head member, their place of origin, and the reasons for building the dwelling. Arrangements were made with the Questura to carry out the census simultaneously in eight different locations, moving from the suburbs towards the centre, using eight groups of officers, under a police superintendent, who shared the work with the Governorate's inspectors. A number was marked on the outer wall of the dwellings that had been surveyed' (Ricci, 1930). The officers of the Questura or the Governorate officials interviewed the heads of 
household and filled in the forms. Once the interviews had been completed, the forms were sent to the UAS, which processed the information jointly with the Governorate's office of statistics.

The Governorate was able to pinpoint the slum areas thanks to monitoring by the special teams of Building Office officials set up in 1925. The task was conducted by an official, a technical assistant, and nine teams of roadmen, who patrolled the nine zones into which the city had been divided.

Without a detailed plan of the census it is impossible to know what the coverage was. However, there can be no doubt that with such a broad survey and such a wide range of information we can at least outline, with a good degree of accuracy, the main sociodemographic characteristics of the slum dwellers.

So far we have focused on the effect that the enormous inflows of migrants had on the development of the slum settlements. In this first part of the study I do not distinguish between the two groups of natives and immigrants, but instead look at them as a whole. For the sake of clarity I should immediately point out that the sample of the baraccati was based on their place of origin. The source, it should be recalled, gives information on the place of birth and year of immigration of the heads of household only. Out of a total of 4,276 people, 3,316 - or roughly $77 \%$ - were born outside the city of Rome, against 960 Romans. These figures show clearly that immigrants made up by far the largest part of the sample; however, they also reveal that the choice of such deprived housing was not just the outcome of a difficult migratory experience.

The gender composition of the sample shows a small preponderance of males, who accounted for $52 \%$ of the total of 19,187 individuals. Heads of household were usually male, but households headed by a woman nonetheless represented almost 10\%. Another aspect is the composition and size of these households, which on average consisted of four members. Most of the households were nuclear families, but often wide family groups lived in the same slum settlement. Figure 2 illustrates household distribution by size, both for slum dwellers and for the whole population of Rome, according to the 1931 census. 
Figure 2: Per cent of households by number of members: Baraccati 1933 and Rome 1931

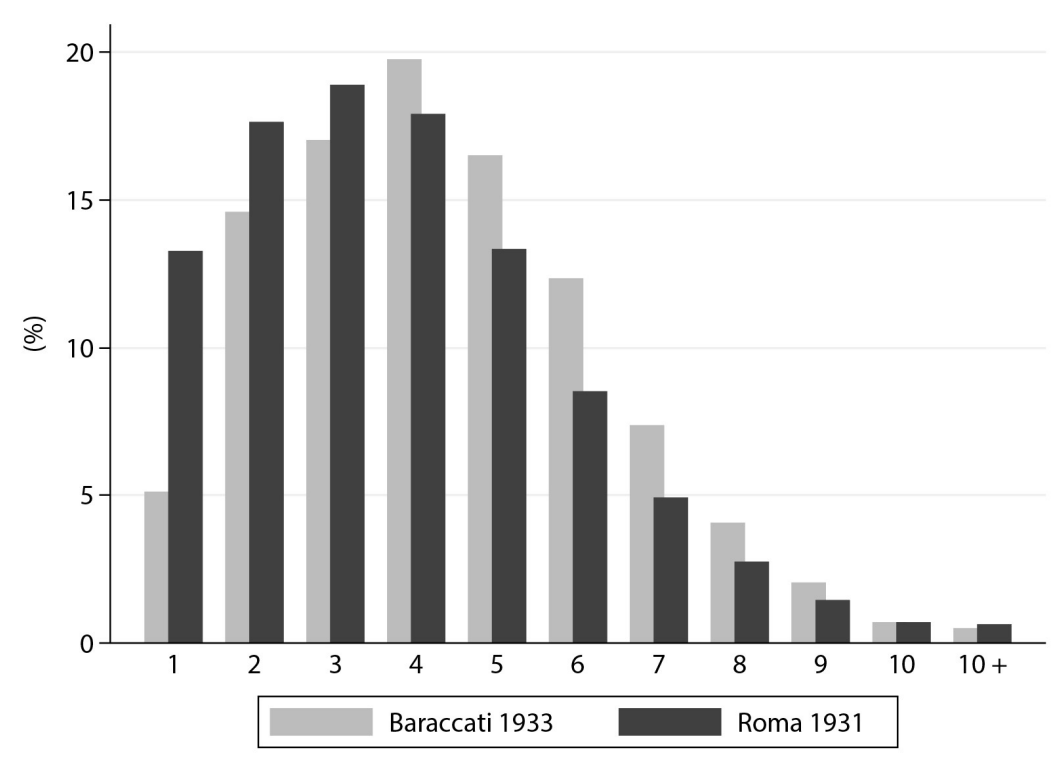

Source: For households of baraccati: Governorate census of 1933. For total households in Rome: General Population Census 1931.

The size of the slum dweller households was not very different from that of the rest of the inhabitants of Rome. The only clear difference relates to one-person households, which were extremely rare, accounting for less than $5 \%$ of the slum dwellers but a much larger proportion in the rest of the city. About $60 \%$ of households had fewer than five members, while the percentage of large families, with more than seven members, was absolutely minimal. The households lived in generally overcrowded conditions, with 2.7 people to each room of the shack. The special housing survey conducted in tandem with the 1931 census shows that the average household in Italy had 1.36 people per room, about half the figure for the slum dwellers.

Figure 3 shows the distribution of the sample by four age cohorts: pre-school (0-6), school age (7-14), active (15-65) and elderly (65+). The population was young, with an average age of about 24 years. More than $40 \%$ was under 14 years of age and $55 \%$ of working age; there were extremely few over-65-year-olds: less than $3 \%$. From this point of view, the distribution of the sample by cohorts describes a very different segment of population from the general average for the city of Rome. According to the same 1931 census, the 
population in the $15-64$ cohort represented more than $70 \%$, while the under- $15 \mathrm{~s}$ were barely $25 \%$.

Figure 3: Distribution of the population of baraccati 1933 and Rome 1931 by age cohorts

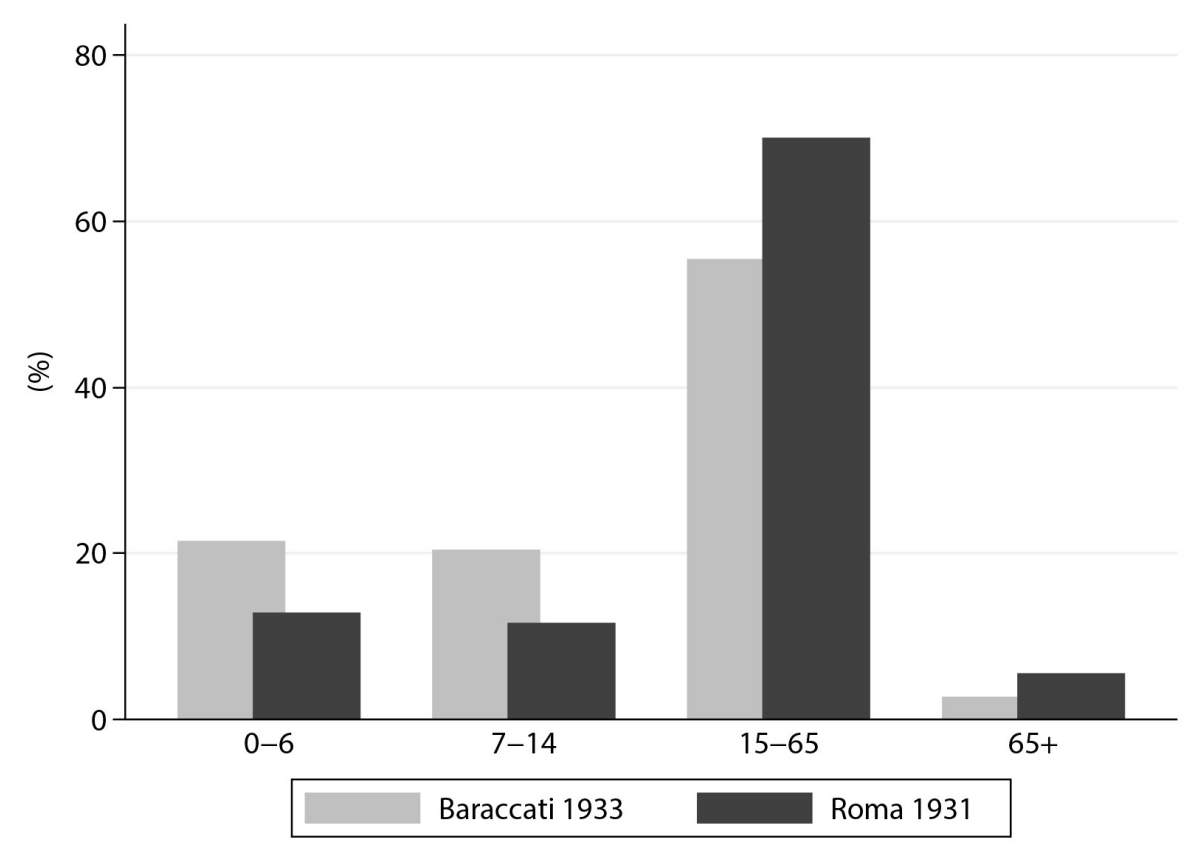

Source: For households of baraccati: Governorate census of 1933.

For total households in Rome: General Population Census 1931.

The population of slum dwellers was thus broadly divided into two groups: about $55 \%$ were of an age to be active and the remaining $45 \%$ were theoretically dependent, with a heavy concentration in the under-14 group. Rome's slum settlements were therefore full of children, many of whom had only ever lived in a slum. Comparing the number of years the household head had spent in a slum settlement with the age of the children (2-10 cohort) and assuming they had always lived together, it emerges that over $60 \%$ were born and had always lived in a slum. The demographic pyramids of the population (figure 4) show even more clearly the presence of a very large number of children, most of preschool age. The size of the working-age population was broadly homogeneous starting from the first, 15-19, cohort up to the 40-44 cohort, decreasing progressively from 45-49 years. Again, there were clear differences with respect to the age distribution of the whole population of Rome (bottom panel). 
Figure 4: Demographic pyramids of the population of baraccati 1933 and Rome 1931

\section{Baraccati 1933}

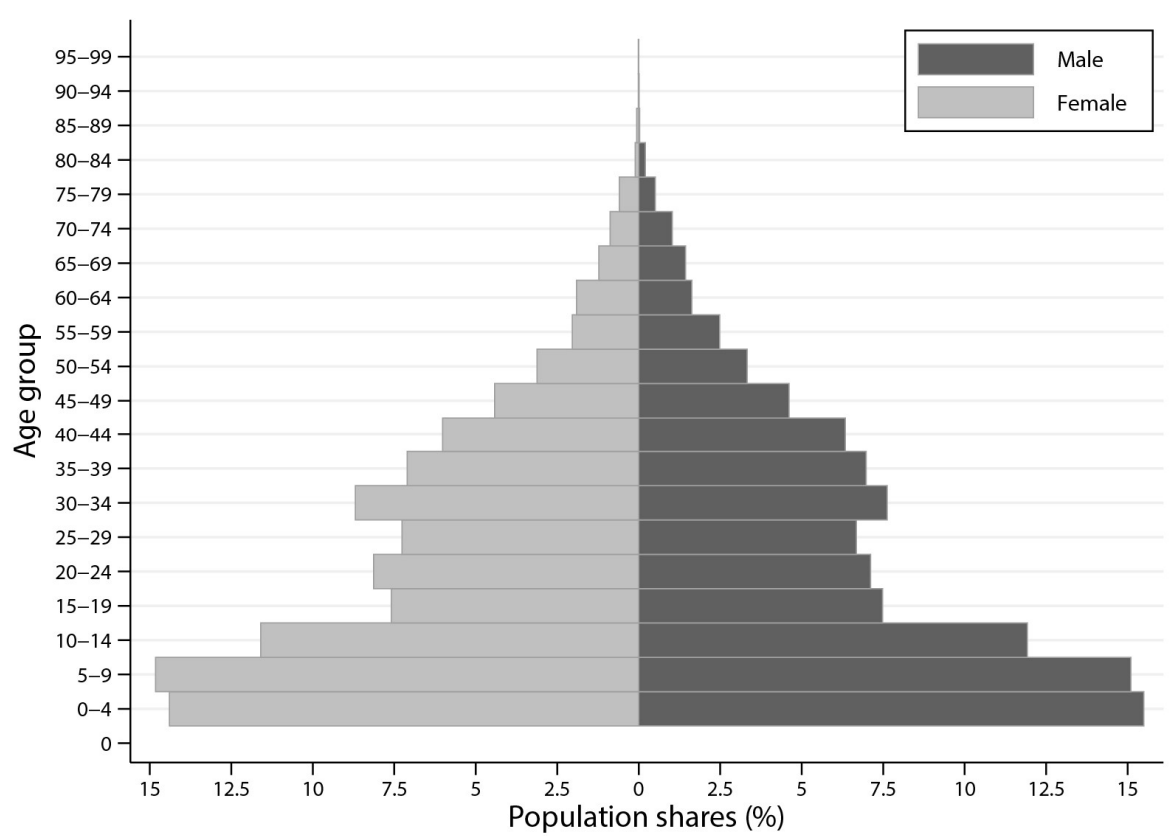

\section{Roma 1931}

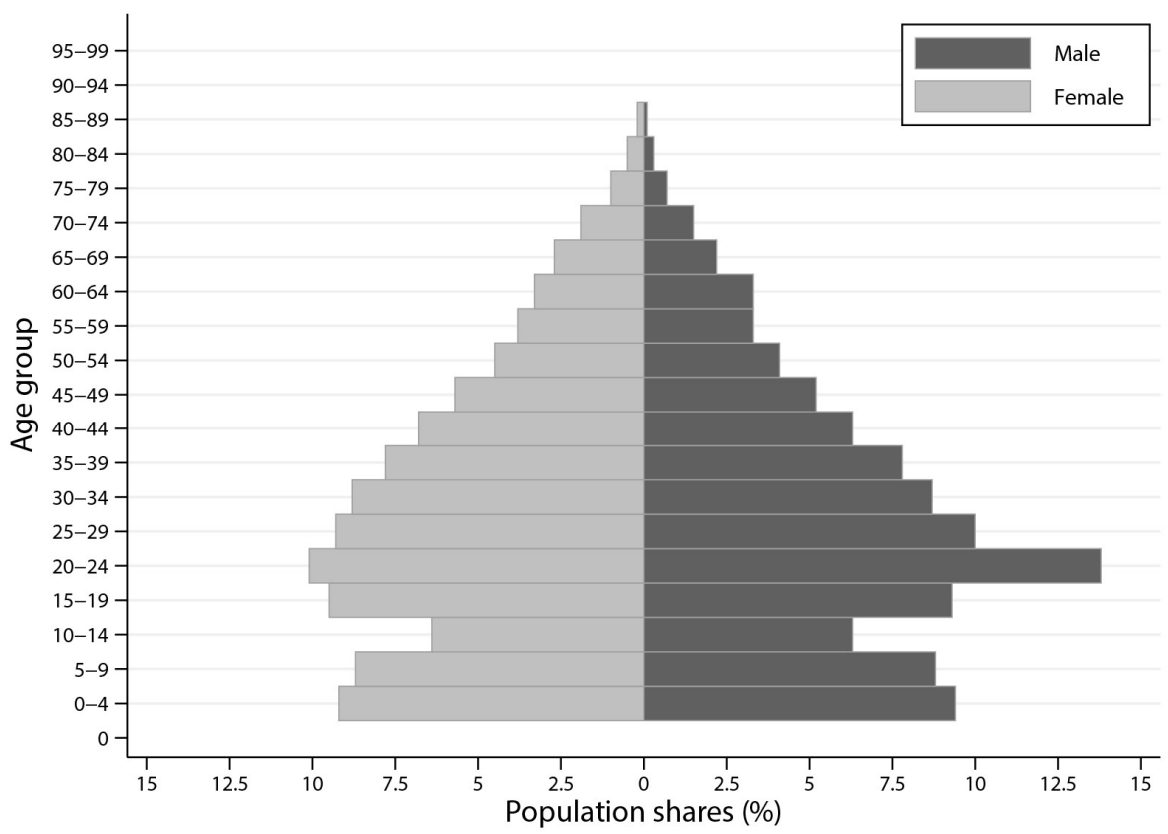

Source: For households of baraccati: Governorate census of 1933. For total households in Rome: General Population Census 1931. 
The children populating the slum settlements lived in conditions of extreme privation. Apart from the general situation of poverty, the basic hygiene and sanitation needed to ensure healthy infant development were, of course, also lacking. Another source of risk was the extremely low rate of school attendance. The Governorate's officials, it should be recalled, collected the information in very raw form; we only know whether or not the children attended school and nothing about their educational level. That said, it is still possible to make some deductions. Taking the whole 6-14 cohort, for which school attendance was compulsory, we know that barely $28 \%$ of the 4,530 children went to school. The results are somewhat surprising if we separate the group into the 6-10 cohort and the 11-14 cohort: the percentage falls to around 25\% for the primary-school group, while $30 \%$ of the 11-14 cohort attended school. School dispersion affected equally boys $(72 \%)$ and girls (74\%). As a final indicator we can try to calculate the gross primary school attendance rate; the numerator is the total 6-10 cohort and the denominator all school attendees. The percentage rises to $45 \%$, which is still extremely low. Recent statistics (A'Hearn, Auria and Vecchi 2012) compute this indicator at regional level: in Lazio in 1931 the gross rate of enrolment at primary school was over $100 \%{ }^{18}$

Having seen that large numbers of children were born and raised in Rome's slum settlements, we can now look more closely at how long their families had lived there. Again, the information relates only to the head of household. Over half of the 4,315 people in the slum settlement surveyed had lived there for less than five years, $25 \%$ from six to ten years, and the remaining $22 \%$ had spent more than ten years in the same slum. Figure 5 shows the distribution of the sample according to the number of years of residence.

\footnotetext{
${ }^{18}$ In this operation values over $100 \%$ are possible because the numerator may be greater than the denominator.
} 


\section{Figure 5: Head of household's years of residence in the slum settlement}

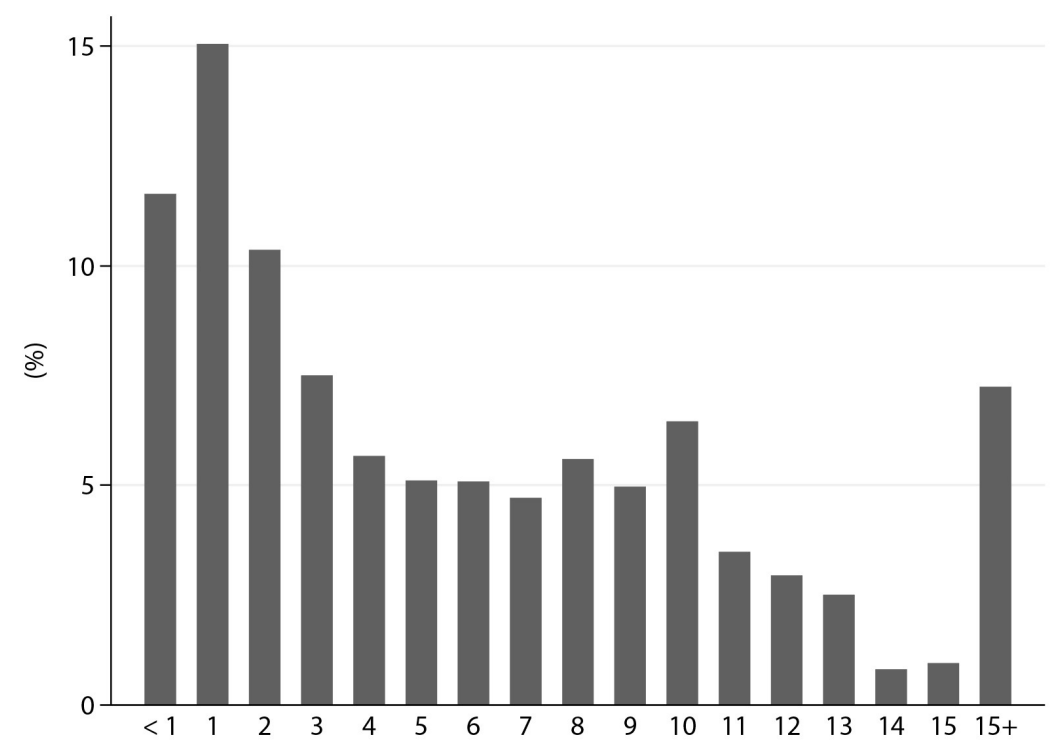

Source: Governorate Baraccati census of 1933.

While the majority of households had lived in these conditions for a fairly short period of time (one to two years), the figure shows that the percentages of long-term residents were by no means residual. Of note, in this connection, is the right-hand tail of the distribution: just under $8 \%$ of the sample had not changed their housing situation for more than fifteen years. Two variables should also be taken into account: first, about two thirds of those living in the slum settlement for less than two years were immigrants whose first experience of living in the city was the slum. Of course, we cannot know how long it would be before they left. Second, about a quarter of the heads of household reported that their previous home had also been a slum settlement, from which they had been evicted. For these households, the slum settlement was not just a temporary solution but a mediumto long-term housing strategy. This finding leads to a set of fundamental consequences regarding, in particular, the living conditions of the baraccati, but also the city's overall model of development. When such deprived living conditions persist for a long time, this has a negative impact on many aspects of general living conditions: 'In general, evidence that poverty affects housing circumstances is stronger than evidence that housing circumstances affect poverty. Nonetheless, it appears that low-cost, decent-quality housing, in an attractive job market, could make a substantial contribution to increasing disposable income, preventing material deprivation and maintaining work incentives. 
There is substantial evidence to show that poor housing conditions affect some aspects of child development and elements of adult health' (Joseph Rowntree Foundation 2013).

Our source allows us to examine in depth a last aspect of the housing situation of the households surveyed: the questionnaire included an item on the reasons why the family had left its previous home. Table 4 records the answers of the heads of household, grouped into seven categories.

Table 4: Reasons given by baraccati for leaving their previous homes

\begin{tabular}{ll}
\hline Reason for moving to the slum settlement & \% \\
\hline Improvement & 25 \\
Financial reasons & 24 \\
Eviction and demolition & 18 \\
Personal reasons & 13 \\
Work & 12 \\
Purchase of land $\backslash$ shack & 4 \\
Other & 4 \\
\hline
\end{tabular}

Source: Governorate Baraccati census of 1933.

Paradoxically, the largest share, about $25 \%$ of the interviewees, reported that they had moved to improve their living conditions. What appears to be in contradiction with the family's housing situation is really a fairly obvious consideration: most of the slum dwellers were migrants, who began their journey with the natural objective of improving their living conditions. The second reason given was financial; this applied mainly to households who were unable to afford the rental of their home and had been evicted after building up large payment arrears. Instead, slightly more than $16 \%$ were homeless because they had been evicted either by a landlord who needed the property or as a result of expropriations and demolitions. Next on the list were personal reasons, generally related to family, specifically marriage or family reunification, and work. A small part of the sample said they had moved after buying the house or the land, evidence of a real if informal market for slum dwellings. 
The settlements listed in the 1933 census were spread over the whole city. They varied considerably in size, from small huddles of less than ten shacks to conglomerations housing hundreds of families. The largest settlements were in the suburbs to the south and east of the city, although considerable groups of shacks also existed much closer in, along the Vatican City Walls and at the foot of the Palatine Hill, right in the historic centre.

Lastly, there is little information about sanitation and the structural conditions of the housing. We know what materials were used to build the homes and also, for part of the sample, the number of rooms. The structure of the shacks was fairly standard: about $75 \%$ were in brick and had two rooms, one communal and one for services. Some $20 \%$ were built of wood and around 4\% of the households surveyed lived in what the Questura officials described as caves. While housing of this last sort implies living conditions of extreme privation, the source bypasses speculation as to quality to let us examine the work situation of the sample and above all to measure income levels.

\section{Employment, income and living conditions}

The most interesting section of the census is, in some respects, the part dedicated to the work and earnings of the individual members of the households. Indeed, it is rare to find surveys with such a broad and well selected sample that look at employment status, type of work, place of work, whether public or private sector, self-employed or employee status, and earnings. It is precisely the information on earnings that allows us to measure, fairly accurately, the levels of wellbeing, internal inequalities and vulnerability to poverty.

In the first place, we will consider the unemployment levels in the sample. The census form included a specific question on employment status. The 5,547 responses indicate an unemployment rate of $30 \%$, a share that stays basically the same for heads of household only. In reality, though, the activity rate was much lower because, as we shall see in more detail below, women were almost completely left out of the calculation as the vast majority of them declared they were housewives and therefore outside the labour market. If we consider the whole working-age population (15-65 years) the activity rate was $33 \%$. Overall, out of a total of 19,219 individuals, only 3,631 were wage earners, just one in 5.3 . 
We can see, in Table 5, the main areas of employment. Construction was the largest sector. This is not surprising because this kind of work is traditionally a last-ditch solution for individuals included in a sample selected among the poorest in the population, and also because construction has always been a driver of the Roman economy. If, in addition to construction, we include the manufacturing sector, in its broadest sense, we arrive at more than $70 \%$ of the total sample. Farmers accounted for no more than $8 \%$, while if we add traders, employees and other service employees, the group represented just over $20 \%$. In the manufacturing industry, unskilled workers were the most prominent group, in particular those transporting materials. Among the skilled workers we find mostly painters, mechanics and printers. There are no particular surprises in the distribution of the types of work, which seem to mirror a fairly typical structure for the sample selected, composed mainly of bricklayers, unskilled workers and others employed in the manufacturing sector.

Table 5: Sectors of employment of the slum dwellers

\begin{tabular}{lc}
\hline Sectors & \% \\
\hline Construction & 38.7 \\
Manufacturing & 31.8 \\
Services & 13.3 \\
Agriculture & 8 \\
Traders & 6.3 \\
Clerks & 1.3 \\
Others & 0.6 \\
\hline
\end{tabular}

Source: Governorate Baraccati census of 1933.

A very interesting piece of information - but one that was reported with little precision or continuity - concerns the slum dwellers' place of work. Many did not volunteer this information, others instead simply gave the address. In about 2000 cases, on the other hand, from the place of work declared it is at least possible to distinguish between public and private sector employment and self-employment. The largest group by far were employees of private firms, with about $64 \%$ of the total, whereas $23 \%$ were public sector 
employees. The most curious aspect is that the vast majority of these were employed by the Governorate itself, i.e. the entity carrying out the monitoring exercise in order to evict them from their homes. They were mainly road sweepers, tram drivers, gardeners and messengers. The remaining 13\% were self-employed workers, in particular small traders, especially street sellers, small restaurant proprietors or owners of small machine shops, often working in a shack built next door to the one they lived in.

We have already mentioned the almost total absence of women in the labour market; let us now look specifically at this question. Working-age women (15-65 years) totalled 5,454 and of these $75 \%$ were housewives, although a further $15 \%$ did not declare their employment status. Therefore, just $10 \%$ of working-age women seem to have had a job, although this figure is probably underestimated. We cannot rule out the possibility that some of these women did occasional or informal work and omitted to declare it on the census form. But, apart from this, it is clear that women's participation in the world of work was, for this segment of the population, extremely limited. This is not a foregone conclusion or one without implications. In the literature on women in the workforce, a higher female employment rate is often assumed for the less well-off classes whose members abandoned the model of the male breadwinner out of necessity (Janssens 1997). For the slum dwellers this standard reasoning does not seem to apply. Of course, the high number of pre-school children and widespread non-attendance of those of school age was a sizeable impediment to female participation in the workforce. However, this probably does not fully explain the figure obtained. In any case, let us now look at the jobs most frequently performed by the women.

Table 6: Employment sectors - women

\begin{tabular}{lc}
\hline Sectors & \% \\
\hline Services & 42 \\
Dressmaking & 19 \\
Manufacturing & 19 \\
Trade & 10 \\
Agriculture & 6 \\
Construction & 3 \\
\hline
\end{tabular}

Source: Governorate Baraccati census of 1933. 
Table 6 illustrates the predominance of the service sector. If we sum those working in trade and those working in the broader service sector, they account for more than $50 \%$ of the sample. The majority of these women worked as domestic help or doing ironing or laundry. But there was no lack of more skilled jobs, in particular in nursing. Many also worked in trade, both as sales assistants in stores and as stall holders or assistants in smaller shops. The manufacturing sector employed $14 \%$ of the sample overall. Half of these worked as weavers, seamstresses or embroiderers. The rest defined themselves as workers in general, while just over 5\% worked in agriculture.

If female labour seems to have been very rare, juvenile workers were practically nonexistent. Barely $4.6 \%$ of children in the 10-15 age group declared they had a job. The percentage rises to $6.5 \%$ if we consider only boys, while just $2.3 \%$ of the girls in the same age group declared they had a job. Overall, we are talking about tens, not hundreds, of individuals: 84 boys and just 27 girls, most of whom were working as apprentices. If we consider the statistics on juvenile labour in Italy, we see an enormous gap with respect to the totals at both the national and the regional level. According to the 1931 census about $27 \%$ of children in Italy worked, while in the Lazio region the percentage fell to just over $24 \%$. Again in this case it is difficult to define the margin of error that the source may contain and it is probable that, as in the case of female labour, the result was underestimated. It is also clear here that juvenile labour was of marginal importance. Such low percentages for both female and juvenile labour also suggest that the labour market was, in many respects, weak and one in which even working-age males found it difficult to find work.

From the point of view of the kinds of jobs done, for these households there seems to be a fairly precise profile. These were single-income households in which the male breadwinner worked in a very low-skilled job. Regardless of the reasons for this, it has direct implications for the wellbeing of the households whose income, in very many cases, was almost exclusively dependent on the earnings of the head of household, who could count on any other income.

At this point, the time has come to attempt to measure and define the income levels of the sample. First, some considerations have to be made as to method. The incomes are given for all members of the household as daily wages; there are very few cases of weekly or monthly wages. This makes it extremely difficult to calculate annual indicators when we 
do not know the actual number of days worked. Daily wages, in any case, help us to make a comparison with the average pay rates recorded in the city for all workers, which are given as daily or hourly rates. The comparison shows a considerable gap between average wages and those declared by the slum dwellers. In 1933 a Roman builder was paid 3.3 lire per hour, around 26 lire per day (Istat 1934). In the same sector, the average daily wage of the slum dweller was 18 lire, $30 \%$ less. Similar percentages are found for both industrial and agricultural workers. Such a marked difference was probably due the fact that the slum dwellers mostly did less skilled work, which was accordingly paid less.

However, the wages tell us little about the effective income level of individuals and households living in the slum settlements. To make a better analysis of income we have to annualize earnings. Given that the source gives us no information as to the number of days worked, for this purpose we use the estimates of Huberman and Minns (2007). ${ }^{19}$

We can use the census data to create budgets of the slum-dweller households, from which we can then calculate the distribution of individual incomes ${ }^{20}$. In the figure 6 , the black line refers to the distribution calculated on the basis of a minimum of 230 days worked, while the grey line corresponds to a maximum of 269 days worked. It was decided to use an upper and a lower bound to show the degree of sensitivity of the curve in relation to changes in the number of days worked. The dotted curve represents the distribution of individual incomes in Italy, while the vertical line marks the absolute poverty line; all the data are set at 1931 values and expressed in euro 2010 values. $^{21}$

\footnotetext{
19 The two authors calculate, on the basis of ILO data, 2,153 hours worked on average in 1929 and 2,162 hours in 1938. I therefore took the average of the two values and divided it by the eight hours of work required by law, to obtain the average number of days worked.

${ }^{20}$ On the use of household budgets in a historical perspective: Chianese and Vecchi (2011) and A'Hearn, Amendola and Vecchi (2016)

21 I would like to thank Giovanni Vecchi and Nicola Amendola for providing me with the income distribution estimates and poverty line for 1931.
} 
Figure 6: Distribution of incomes of the sample of Slum dwellers (solid black and grey curves) and of the Italian population in 1931 (dotted curve). The vertical line represents the Italian poverty line for the year 1931

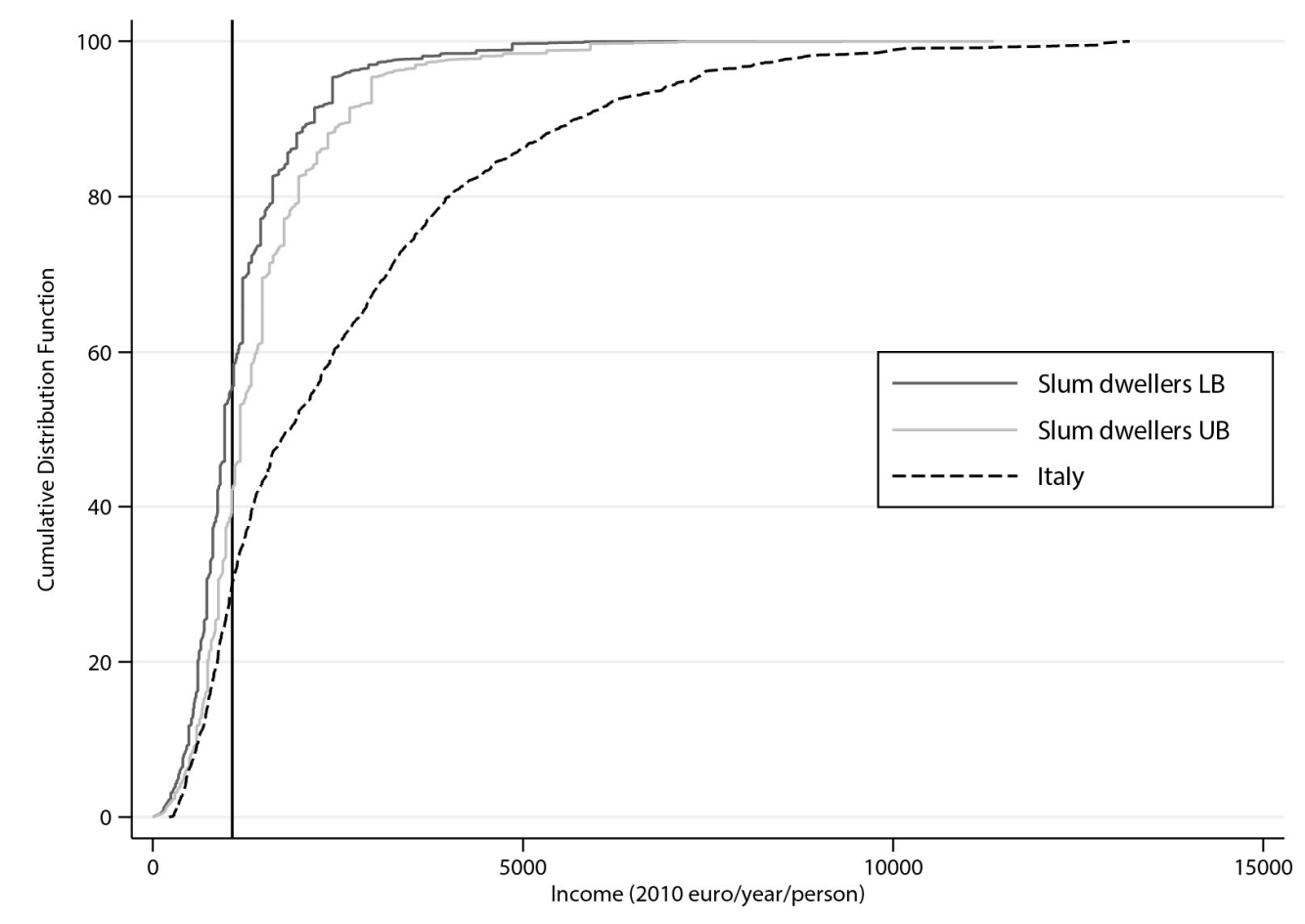

Sources: For the Slum dwellers' income distribution curve: Governorate census of 1933. For the national distribution curve and the poverty line: Amendola, Salsano and Vecchi (2011).

One of the first calculations is the rate of absolute poverty: if the figure for Italy stood at $30 \%$, for the slum dwellers it was between $45 \%$ and $55 \%$. There is, however, an important consideration to be made to achieve a more balanced estimate: the poverty line, indicated in the figure, is an average value referring to the Italian population as a whole, and it is calculated on the basis of the average number of calories an individual needs to consume multiplied by the lowest possible cost of one calorie. While it is possible to adapt the calorie requirement variable to our sample, it may not be so in the case of the cost of one calorie. Living in Rome, the slum dwellers had a higher cost of living than the national average. Unfortunately, we do not have any accurate time series on spatial differentials and it is difficult to establish a multiplier of the cost of living in Rome compared with the national average. Given the shape of the curves, however, it is clear that, because of the higher cost of living, even a slight movement would raise the poverty rate to very much higher values. The slum dwellers counter the unaffordable cost of housing by adopting a strategy that reduces their standard of living. Spatial differences in living costs clearly reflect different levels of expenditure on housing, leading to significant disparities in 
wellbeing between different areas of a country: 'Housing costs constitute the most important and most direct impact of housing on poverty and material deprivation. Variations in housing costs between places also have a substantial impact. The number of Londoners living in poverty almost doubles to just over two million once housing costs are taken into account' (Tunstall et al. 2013).

What is happening in contemporary London is, on a larger scale, similar to what was observed in the Rome in the Fascist era: massive immigration that causes an inevitable sharp rise in housing demand and supply which affects the population's living conditions as a whole. It is virtually impossible to consider slum dwellers as outside the definition of poverty. The example of the baraccati clearly indicates the multidimensional aspect of poverty: we cannot assess the income data except through the lens of their living conditions as well.

Apart from considerations regarding the number of individuals living in poverty, it is interesting to note the degree of inequality within the sample. In Table 7 we observe the average income values for each decile, again expressed in euro 2010 values and calculated in individual terms.

Table 7: Per capita average incomes by decile and average household size

\begin{tabular}{ccc}
$\begin{array}{c}\text { Deciles } \\
\text { (euro 2010 value) }\end{array}$ & $\begin{array}{c}\text { Average } \\
\text { income }\end{array}$ & $\begin{array}{c}\text { Average } \\
\text { household size }\end{array}$ \\
\hline 1 & 368.2 & 6.2 \\
2 & 638.9 & 5.9 \\
3 & 785.0 & 5.7 \\
4 & 930.4 & 5.2 \\
5 & 1073.8 & 4.6 \\
6 & 1223.9 & 4.7 \\
7 & 1370.2 & 3.9 \\
8 & 1670.6 & 3.7 \\
9 & 2202.5 & 2.8 \\
10 & 3521.2 & 2.1 \\
\hline
\end{tabular}

Source: Baraccati census of 1933. 
The table shows a sizeable difference in income within the sample: the average income of the first decile is ten times less than that of the tenth, and calculating the average of the five lowest values and five highest values we find a difference of close to $130 \%$. Looking at the third column of the table, one finding emerges very clearly: household size is a decisive factor in determining individual income. This is very much in line with what we have already observed, given that the wage earners are very few in slum dweller households and therefore it is fairly obvious that smaller households will have higher individual incomes. We should ask ourselves, on the basis of an income structure of this type, why the women did not find work and why the younger members did not contribute. A possible answer lies in the high percentage of immigrants, whose lack of resources and relations in the city made it more difficult to find work, especially for some categories. However, it was the type of immigrants found in the Roman slums that created a further gap. The migration flows towards the capital were not, as we will see in the next section, all the same, and the portion we study is that selected most negatively, i.e. immigrants with little training for work and for whom migration did not lead to better living conditions.

\section{Internal migration during Fascism}

This article does not aim to draw an overall picture of internal mobility in Italy in the interwar years. Instead, I will focus on a number of themes, particularly those relating to the push and pull factors of emigration.

Between the two World Wars emigration was a factor in transforming the size, the functions and the social and economic structures of Italy's major cities. 'It was during those two decades, in fact, that the major cities expanded, outgrowing the ancient borders of administrative areas ... Their functions were refined and became increasingly diversified as the economic system evolved and grew in complexity' (Treves 1976).

The second great transformation was more specifically economic in nature. While throughout the liberal age poverty was chiefly a problem of farmers and rural areas, during Fascism a significant change of perspective occurred. The result was a mass exodus from the countryside and small rural centres towards the big cities (Gallo 2012). Many urban 
centres were affected, as we can see in Table 8, which compares the population data for the major cities in the 1921 and the 1936 censuses.

Table 8: Population increase in the main urban centres (1921-1936)

\begin{tabular}{cccccccccc}
\hline \multicolumn{7}{c}{ Population growth (1921-1936) - absolute values } \\
& Rome & Milan & Turin & Genoa & Bologna & Naples & Palermo & Italy \\
\hline $\mathbf{1 9 2 1}$ & 660,091 & 818,148 & 499,823 & 541,562 & 212,754 & 856,629 & 397,486 & $38,449,000$ \\
$\mathbf{1 9 3 6}$ & $1,150,338$ & $1,115,768$ & 629,115 & 634,646 & 281,162 & 865,913 & 411,879 & $42,994,000$ \\
Difference & 490,247 & 297,620 & 129,292 & 93,084 & 68,408 & 6,284 & 14,393 & $4,545,000$
\end{tabular}

Population growth (1921-1936) - percentage changes

\begin{tabular}{ccccccccc} 
& Rome & Milan & Turin & Genoa & Bologna & Naples & Palermo & Italy \\
\hline $\mathbf{1 9 2 1} \backslash \mathbf{1 9 3 6}$ & 74 & 36 & 26 & 17 & 32 & 0.7 & 3.6 & 11.8
\end{tabular}

Source: Central Statistical Institute 1921, Istat 1936.

Apart from what has already been noted concerning Rome, rates of population growth were high in the cities of central and northern Italy. Milan's population grew by almost $40 \%$ in the space of fifteen years, that of Turin and Bologna by almost $30 \%$, and Genoa's by close to $20 \%$. The situation in the large cities of the south was the complete opposite, with virtually no demographic growth: barely $4 \%$ in Palermo and less than $1 \%$ in Naples. A number of factors were behind this massive movement, prompting large swathes of the rural population to head for the cities.

To begin with, economic history concurs almost unanimously that the twenty years of Fascism greatly impoverished the country's agricultural economy (Toniolo 1980; Nützenadel 2001). All the most important economic policies, from the 'Quota 90' revaluation of the lira to the 'Battle for Grain' drive for self-sufficiency, had adverse repercussions on an already fragile rural Italy.

The Great Depression, too, had a deeper impact on the countryside than on the cities. The population increase and closure of the borders were further fuses lighting the ticking bomb of migration. While the rural economic crisis explains much of the population exodus 
from the Italian countryside, it is far more difficult to understand what attraction Rome, in particular, exerted over the rural masses. There is no specific evidence of economic expansion in the city sufficient to justify such huge migration. Rome was, and still is, a city with little industry, as data on the number of industrial workers taken from the two censuses confirm. In Table 9 we see that from 1927 to 1938 the number of workers in industry as a whole did increase somewhat, from just short of 100,000 to about 160,000. However, if we separate the different sectors of production it emerges that in reality almost all of that increase was in the construction sector, which, as pointed out, was one of the few sources of the city's economic growth.

Table 9: Increase in workers in industry as a whole and in the construction sector: Rome 1927-1938

\begin{tabular}{cccc}
\hline & $\mathbf{1 9 2 7}$ & $\mathbf{1 9 3 8}$ & Difference \\
\hline Total industry & 104,604 & 163,084 & 58,480 \\
Only construction & 17,069 & 62,000 & 44,931 \\
\hline
\end{tabular}

Source: Istat, censuses of industry 1927-1938.

Therefore, one of the first forces of attraction was probably the growth of the housing sector and the relative ease of finding work there. Construction was not the only outlet for the city's labour market, however. Another sector was in constant expansion: 'In 1921 employees of the public administration numbered 472,000, ten years later 543,000 and in 1936 there were 683,000 . Thoughts turn immediately to Rome, the metropolis without industry, the great head of the apparatus of bureaucracy' (Treves 1976). The growth of the service sector was driven, first and foremost, by the huge bureaucratic machinery of the regime, which called for a wide variety of occupational profiles. Messengers, clerks and officials peopled the numerous government and semi-governmental bodies set up during the period, most of which had their headquarters in the capital.

Yet the housing boom and state bureaucracy could not, by themselves, absorb such a large wave of migration. Those arriving in Rome during those years often had no other real alternative and simply joined the city's huge pool of unemployed or occasional workers. This was migration driven more by desperation than by expectations of an actual improvement in living conditions. "Those who abandon the countryside try ... to crowd 
into the cities. They do so less because they are attracted by the prospect of a job in industry and more because they hope they will have a better chance to get by, to obtain various types of benefit or aid, which for obvious reasons are more likely to be handed out in the towns than in the countryside' (Sylos Labini 1954). This mass of new town dwellers, expelled from the countryside, with few resources and no particular work skills, had to overcome the difficulties of integrating into a social and economic fabric in many respects far from inclusive. Many of them ended up in the vast slums of the capital.

\section{Immigrants in the slum settlements}

The immigrants analysed here on the basis of the Baraccati censuses therefore represent a narrow group selected from the overall flow of migration. It is, of course, a negative selection: people with few work skills for whom migration has been a failure. We cannot know the situation of these households before their arrival in Rome and therefore have no reliable term of comparison; however, living in a slum is unlikely to be an improvement in housing and living conditions. Moreover, this type of migration is very hard to capture in statistics and official surveys: 'While there is evidence that the poorest, least skilled, least physically capable and those without networks tend to migrate less, it is also true that the types of migration the poorest engage in are less likely to be captured in surveys and censuses' (Arjan de Haan and Shahin Yaqub 2009). The Baraccati census, on the other hand, does capture the group composed above all of extremely vulnerable people with few social, economic or job prospects. Let us attempt to define their main characteristics.

As pointed out earlier, $77 \%$ of the heads of household were not born in Rome. Most of the slum dwellers migrated to Rome from nearby: more than $30 \%$ came from the province of Lazio. A further $40 \%$ came from the three main regions of the centre and south on the Adriatic Sea: in order, Marche, Puglia and Abruzzo. A smaller share of migrants came from other regions, in addition to which were $2 \%$ of return migrants, some forty families from South America and northern Europe who had returned to Italy and found themselves in Rome's slums. 
Table 10: Main regions of origin of the Baraccati 1933 households

\begin{tabular}{lc}
\hline Region of origin & \% \\
\hline Lazio & 32.1 \\
Marche & 16.4 \\
Puglia & 12 \\
Abruzzo & 11 \\
Umbria & 6.1 \\
Emilia Romagna & 5.5 \\
Tuscany & 3.6 \\
Sardinia & 2.5 \\
Campania & 2.5 \\
Sicily & 1.9 \\
Other & 6.4 \\
\hline
\end{tabular}

Source: Governorate Baraccati census of 1933.

The breakdown by province of origin further highlights both of the characteristics described. Rome was the most heavily represented province, followed by Bari with just under $10 \%$ and L'Aquila with $8 \%$. The provinces of Rieti, Frosinone, Pesaro and Perugia each contributed around 5-6\%. With the exception of Bari, the main provinces of southern Italy are markedly absent. As was already apparent from the 1929 census, most of the migrants arrived in Rome from the regions and provinces to the east of the country. The data clearly reflect one of the two geographical traits that have divided Italy since its foundation. Apart from the traditional north-south split, there is an equally marked separation between east and west that mirrors the location of the old, pre-unification capitals and the associated activities that made up most of the non-agricultural sector in a largely pre-industrial Italy (Fenoaltea 2011) 
Table 11: Main provinces of origin of the Baraccati 1933 households

\begin{tabular}{lc}
\hline Province of origin & \% \\
\hline Rome & 14.2 \\
Bari & 9.2 \\
Aquila & 7.5 \\
Rieti & 6.5 \\
Frosinone & 6.3 \\
Pesaro & 5.1 \\
Perugia & 4.7 \\
Viterbo & 4.2 \\
Ancona & 3.7 \\
Ascoli & 3.7 \\
Macerata & 3.6 \\
Forli & 3.1 \\
Foggia & 2.2 \\
Teramo & 1.9 \\
Other & 24.1 \\
\hline
\end{tabular}

Source: Governorate Baraccati census of 1933.

Looking at the dynamics of overall migration towards Rome some significant differences are apparent in this respect. Figure 7 shows the regions of origin of Roman immigrants from 1926 to 1934 . It bears out the observation regarding the Adriatic regions and highlights the difference with respect to the regions in the south. Immigrants from Campania, Calabria and Sicily jointly accounted for barely $5 \%$ of the baraccati, while in terms of overall migration they represented between $11 \%$ and $14 \%$. It is not easy to explain this difference, which could be partly the result of relationship dynamics, of family networks that led to certain regional groups prevailing over others. It may also be that the selection of migration flows that we find inside the slum settlements led to some geographical areas being more represented than others. 
Figure 7: Regions of origin of immigrants to Rome (1926-1934)

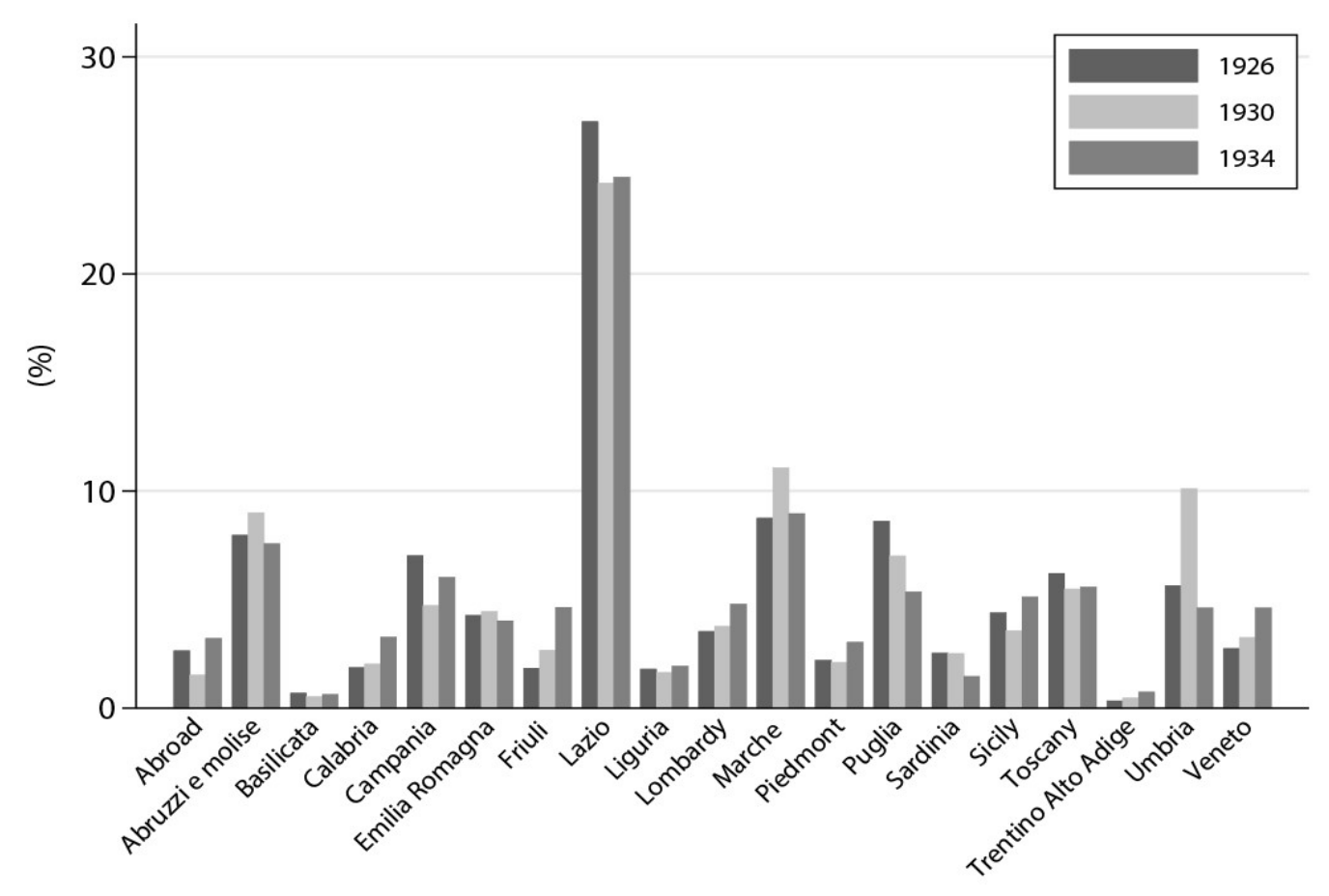

Source: Istat, Rilevazione del movimento e calcolo della popolazione residente (1926-1934).

Of note is the preponderance, among the baraccati, of rural migrants. This variable is measured using information on the municipal districts of origin, for the most part small centres or hamlets based around agriculture. Rural migrants generally represented over $90 \%$ of the sample, and this could account for the predominance of certain areas of origin over others.

The role of networks of friends and family has been mentioned, and in fact the theme of chain migration is among the most widely studied in the literature (Magobunje 1970; Massey et al. 1993; Dustmann and Glitz 2005; de Haas 2009). It is a typical feature of migration in general and was present among the baraccati. Many family groups are part of broad chains of migration, as in the case of the migrants from small centres such as Cagli in the province of Pesaro, from which 37 households came, Capranica Prenestina in the province of Rome, which yielded 45 households, and Cerignola, whose 60 households were crowded together in slum settlements on the outskirts of the city. All these groups came from rural hamlets and were linked by loose family ties. The format was fairly standard: the arrival of a group of 'pioneers' would be followed by the arrival of other households, boosting their presence within a given slum area and eventually occupying 
large parts of it. Some migration chains managed to specialize in specific jobs, as did a number of families from the village of Andria in the province of Barletta. In their case, not only did the households occupy dwellings in the same settlement, they also succeeded in creating a common job pathway: at least 182 families with a total of 820 members came from Andria, some of whom - about 20 household heads and 45 members - found work in the city with the same firm, Vaselli, all as cleaners. This migration chain not only lived in the same settlement, but also acquired a common specialization, with a whole family group finding work in the same firm. Even among the baraccati, therefore, networks, family and otherwise, were important in shaping migration strategy and facilitating integration into the local job market.

Thanks to the census we are also able to observe the amount of time these households spent in the city. As Table 12 shows, arrivals increased sharply in the aftermath of World War I, indicating a well-established group of migrants but one that obviously was unable to integrate fully and effectively into the city's social structure.

Table 12: Year of household head's arrival in Rome, in five year periods

\begin{tabular}{lc}
\hline Years & $\%$ \\
\hline $\mathbf{1 8 6 4 - 1 8 9 8}$ & 11.6 \\
$\mathbf{1 8 9 9 - 1 9 0 3}$ & 6.4 \\
$\mathbf{1 9 0 4 - 1 9 0 8}$ & 4.4 \\
$\mathbf{1 9 0 9 - 1 9 1 3}$ & 8.6 \\
$\mathbf{1 9 1 4 - 1 9 1 8}$ & 7.4 \\
$\mathbf{1 9 1 9 - 1 9 2 3}$ & 25.7 \\
$\mathbf{1 9 2 4 - 1 9 2 8}$ & 23.2 \\
$\mathbf{1 9 2 9 - 1 9 3 3}$ & 12.6 \\
\hline
\end{tabular}

Source: Baraccati census of 1933.

The data on the year of arrival allows us to examine the phenomenon further. In attempting to understand the nature of a migration flow it is very important to know whether it consisted of established families or of single men and women who set out to migrate on their own initiative. The difference is an important one. For a family with children, the 
decision to migrate entails a series of problems that individuals do not encounter. The latter have less difficulty adapting to harsh living conditions and may even be willing to tolerate comfortless housing or accept more precarious work. Our source can, to some extent, help to answer this question. While we do not know the marital status of the migrants before leaving, we do know whether any children were born before or after their arrival in Rome. Overall, considering the total number of children of all the immigrant families, it emerges that only $24 \%$ were not born in Rome. We can take this calculation further and count how many families arrived in the city without children. Again the finding is very clear: some $74 \%$ of heads of household did not have children before arriving in Rome. It is clear, therefore, that these migrants were mostly single people or childless young couples who then started their families once in Rome. However, these families were not formed as a result of the migrants' integration into their place of arrival: they remained marginalized and their living conditions continued to be extremely precarious.

\section{Conclusions}

The baraccati were undoubtedly only a small portion of Rome's population and merely part of the complex phenomenon of migration that affected the city between the $1920 \mathrm{~s}$ and 1930s. Their housing and living conditions were by no means representative of the general population during those two decades: they were the most exposed and visible element, the most vulnerable, without the means to deal with a clearly complex economic situation. Nevertheless, they are evidence of a general problem facing both the city and the country as a whole which had repercussions on one of the factors that determine a population's standard of living: housing conditions.

A study of the phenomenon of the baraccati leads on to a more thorough examination of the issue of housing conditions not only in Rome but in Italy's other major cities as well. As we have seen, during the twenty years of Fascism the size, functions and socioeconomic structures of Italy's cities underwent a profound transformation. Migration brought to the cities large pockets of poverty as well, setting new and complex challenges for the country's welfare policy. The countryside has other means of safeguarding against poverty with respect to the city. Networks of friends and relations, being able to grow one's own food, and a very low cost of living are important bulwarks against the risk of 
extreme indigence. In the city, particularly for immigrants, it should be the welfare institutions that provide the means of subsistence and enact active policies to combat poverty. The literature increasingly emphasizes the consequence of migration flows on the welfare state (Borjas and Trejo 1991, 1993; Borjas and Hilton 2008; de Giorgi and Pellizzari 2009) and especially on social housing (Rutter and Latorre 2009, Battiston et al. 2014).

The Fascist regime's strategy for combating the urban drift made it extremely difficult to organize generalized measures to integrate the immigrants. Yet it was the regime's welfare system that had to tackle the problem. As we have seen, the efforts of the Governorate's Social Assistance Office were basically directed at limiting the phenomenon and did not include any strategy to integrate the newcomers. To draw a fuller picture of the situation the study would require access to a broader range of documents referring to all the institutions involved. The Governorate itself was directly responsible for numerous reception facilities and social housing, producing documentation that provides a large amount of data on the households applying for benefits and on their individual members. Applications for housing contain information on the composition of the household, the place of origin of each member, their occupation, their financial situation and much more. The fond is enormous: there were tens of thousands of applications during those twenty years. Using this type of documentation has the advantage, as in the case of Rome's slum dwellers, of focusing the analysis on households, in line with most of the literature studying modern migration phenomena and the link to poverty: 'Using households rather than places as the unit of analysis is appropriate for a number of reasons. First, it sits more comfortably with sociological and anthropological analysis. Second, it takes better account of the fact that much, if not most, migration is "circular", with continued interactions with areas of origins rather than a one-way and one-off move. Third, a focus on households should, in principle, make it easier to incorporate findings from the dominant kind of poverty analysis' (Arjan de Haan and Shahin Yaqub 2009).

It is extremely rare to find a source with characteristics such as those of the Baraccati censuses. But searching among the pages of the documents produced by the main welfare bodies of the time it is apparent that there is still much unexplored territory that can be used to reconstruct the links between migration, poverty and housing conditions in such an important phase of the social and economic history of Italy and its capital. 


\section{References:}

A’Hearn, B., Amendola, N., Vecchi, G. (2016). On Historical Household Budgets. Rivista di storia economica, 2/2016, pp. 137-176

Amendola, N., Salsano, F., Vecchi, G. (2011). Povertà. In: In ricchezza e in povertà : il benessere degli italiani dall'unità a oggi. Bologna: Il Mulino.

Ardeni, P. G. (2015). Across the Ocean to the Land of Mines: Five Thousand Stories of Italian Migration from the Mountains of Bologna and Modena to America at the Turn of the Twentieth Century. Bologna: Pendragon.

Associazione 21 luglio (2016), Roma: Oltre le baraccopoli. Agenda politica per ripartire dalle periferie dimenticate. http://www.21luglio.org

Battiston et al. (2014), Immigration and the Access to Social Housing in the UK. CEP Discussion Paper, 1264.

Bevilacqua, P., De Clementi, A. and Franzina, E. (2001). Storia dell'emigrazione italiana. Rome: Donzelli.

Berlinguer, G. and Della Seta, P. (1976). Borgate di Roma. Rome: Editori Riuniti.

Bonomo, B.(2003). Dalla borgata di Prato Rotondo al quartiere Magliana. Storia di una comunità di immigrati nella Roma del secondo dopoguerra. Giornale di Storia Contemporanea, VI, pp. 77-99.

Borjas, George J. (1987). Self-Selection and the Earnings of Immigrants. The American Economic Review, 77(4), pp. 531-553.

Borjas, G. and Trejo, S. J. (1991). Immigrant Participation in the Welfare System. Industrial and Labor Relations Review, 44(2), pp. 195- 211.

Borjas, G. and Trejo, S. J. (1993). National Origin and Immigrant Welfare Recipiency. Journal of Public Economics, 50(3), pp. 325- 344

Borjas, G. and Hilton, L. (2008). Immigrants and Welfare Programmes: Exploring the Interactions between Immigrant Characteristics, Immigrant Welfare Dependence, and Welfare Policy. Oxford Revue of Economic Policy, 24(3), pp. 542-559

Cannari, L., D'alessio, G. and Vecchi, G. (2016). I prezzi delle abitazioni in Italia, 19272012. Temi di Discussione (Working Papers). Rome: Banca d'Italia.

Cannari, L., Nucci, F. and Sestito, P. (2000). Geographic Labour Mobility and the Cost of Housing: Evidence from Italy. Applied Economics, 32, pp. 1899-1906. 
Cederna, A. (1956). I vandali in casa. Bari: Laterza.

Cederna, A (1965). Mirabilia Urbis. Turin: Einaudi.

Cederna, A. (1979). Mussolini urbanista. Lo sventramento di Roma negli anni del consenso. Rome-Bari: Laterza.

Chianese S. and Vecchi G. (2011) Bilanci di famiglia. In: In ricchezza e in povertà : il benessere degli italiani dall'unità a oggi. Bologna: Il Mulino.

Chiswick, B. (1999). Are Immigrants Favorably Self-Selected? American Economic Review (American Economic Association), 89(2), pp. 181-185.

D'Apice, C., Mazzetti G. (1970). Roma: la citta contro l'uomo. Rome: Schirru.

De Giorgi, G. and Pellizzari, M. (2009). Welfare Migration in Europe. Labour Economics, 16(4), pp. 353-363.

de Haan, A. (1999). Livelihoods and poverty: The Role of Migration. A Critical Review of the Migration Literature. Journal of Development Studies, 36(2), pp. 1-47.

de Haan, A. and Yaqub, S. (2009). Migration and Poverty. Linkages, Knowledge Gaps and Policy Implications. Social Policy and Development Programme, Paper Number 40.

De Haas, H. (2010). The Internal Dynamics of Migration Processes: A Theoretical Inquiry. Journal of Ethnic and Migration Studies, 36(10), pp. 1587-1617.

Dustmann, C. and Albrecht, G. (2005). Immigration, Jobs and Wages: Theory, Evidence and Opinion. Centre for Research and Analysis of Migration. London: CEPR.

Fenoaltea, S. (2011). The Reinterpretation of Italian Economic History: From Unification to the Great War. New York: Cambridge University Press.

Ferrarotti, F. (1974). Vite di baraccati. Contributo alla sociologia della marginalità. Naples: Liguori.

Gallo, S. (2012). Senza attraversare le frontiere: le migrazioni interne dall'unità a oggi. Rome: Laterza.

Gomellini, M. and O' Gráda C. (2011). Outward and Inward Migrations in Italy: A Historical Perspective. Temi di Discussione (Working Papers). Rome: Banca d'Italia.

Gonzalez, L. and Ortega, F. (2009). Immigration and Housing Booms: Evidence from Spain. IZA Discussion Papers, 4333. Institute for the Study of Labor (IZA). 
Harris, J. and Todaro. M.P. (1970). Migration, Unemployment and Development: A TwoSector Analysis. American Economic Review, 60, pp. 126-142.

Huberman, M. and Minns, C. (2007). The Times They Are Not Changin': Days and Hours of Work in Old and New Worlds, 1870-2000. Explorations in Economic History, 44, pp. $538-567$.

Insolera, I. (1962). Roma moderna: un secolo di storia urbanistica. Turin: Einaudi.

Insolera, I. and Perego, F. (1999). Archeologia e città. Storia moderna dei Fori di Roma. Rome-Bari: Laterza.

Insolera, I. (2001). Roma fascista nelle fotografie dell'Istituto Luce. Rome: Editori Riuniti.

ISTAT (1928). Censimento industriale e commerciale: al 15 ottobre 1927. Rome: Provveditorato generale dello Stato.

ISTAT (1931). Annuario statistico italiano. Terza serie, Vol. 5. Rome: Istituto Poligrafico dello Stato.

ISTAT (1934). Annuario statistico italiano. Quarta serie, Vol. 1. Rome: Istituto Poligrafico dello Stato.

ISTAT (1936). Censimento generale della popolazione: 21 aprile 1936. Rome: Tipografia F. Failli.

ISTAT (1943). Censimento industriale e commerciale 1937-40. Rome: Tipografia F. Failli.

ISTAT (2016). Rilevazione del movimento e calcolo della popolazione residente. http://seriestoriche.istat.it/

Istituto centrale di statistica (1922). Popolazione censita al 1. dicembre 1921: risultati del 6. censimento della popolazione del Regno d'Italia. Rome: Tip. coop. Sociale.

Janssens, A. (1997). The Rise and Decline of the Male Breadwinner Family? An Overview of the Debate. International Review of Social History, null, pp. 1-23.

Kalantaryan, S. (2013). Housing Market Responses to Immigration; Evidence from Italy. EUI Working Paper, RSCAS 2013/83.

Lee, E. S. (1966). A Theory of Migration. Demography, 3(1), pp. 47-57.

Mabogunje, A. (1970). Systems Approach to the Theory of Rural-Urban Migration. Geographical Analysis, 2, pp. 1-18. 
Maroi, L. (1941). Incremento naturale e incremento artificiale della popolazione di Roma. Capitolium, 12.

Massey, D. S., Arango, J., Graeme, H., Kouaouci, A., Pellegrino, A. and Taylor, J.E. (1993). Theories of International Migration: A Review and Appraisal. Population and Development Review, 19(3), pp. 431-466.

Mokyr, J. and Ó Gráda, C. (1982). Emigration and Poverty in Prefamine Ireland. UCD Centre for Economic Research Working Paper Series, 1, 1982.

Nützenadel A. (2001). Economic Crisis and Agriculture in Fascist Italy, 1927-1935. Some New Considerations. Rivista di Storia Economica, a. XVII(3).

Perego, F. and Clementi, A.(1983). La metropoli "spontanea", il caso di Roma : 19251981 sviluppo residenziale di una città dentro e fuori dal piano. Bari: Dedalo.

Ricci, R. (1930). Baracche e sbaraccamenti. Capitolium, 3, pp. 142-149.

Roy, A. D. (1951). Some Thoughts on the Distribution of Earnings. Oxford Economic Papers, 3(2), pp. 135-146.

Rutter, J. and Latorre, M. (2009). Social housing allocation and immigrant communities. EHRC Research Report Series, 4.

Saiz, A. (2003). Room in the kitchen for the melting pot: immigration and rental prices. The Review of Economics and Statistics, 85(3), pp. 502-521

Salvatori, P. (2006). Il Governatorato di Roma. L'amministrazione della capitale durante il fascismo. Milan: Franco Angeli.

Salvucci G. (2014). Immobili “instabili” nella ricostruzione della capital. In: Atti del VI congresso AISU. Catania: Scrimm, pp. 1325- 34

Santori, A. (1984). La politica sociale del Governatorato. In: L'economia italiana tra le due guerre 1919-1939. Milan: Ipsoa, pp. 510-2.

Sylos Labini, P. (1954). L'emigrazione dal Mezzogiorno verso il Centro ed il Settentrione. In: Atti della I riunione scientifica dell'Istituto italiano di Studi della protezione sociale. Rome: Tipografia Garzanti.

Talamona, M. (1958). Fluttuazioni edilizie e cicli economici: Ricerche sul comportamento degli investimenti in abitazioni in Italia dal 1863 al 1945. Rome: Istituto nazionale per lo studio della congiuntura.

Toniolo, G. (1980). L' economia dell'Italia fascista. Rome: Laterza. 
Toniolo G. ed. (2013). The Oxford Handbook of the Italian Economy since Unification. Oxford: Oxford University Press.

Treves, A. (1976). Le migrazioni interne nell'Italia fascista: politica e realtà demografica. Turin: Einaudi.

Tunstall, R. et al. (2013). The Links between Housing and Poverty: an Evidence Review. York: Joseph Rowntree Foundation.

Salvucci, G. (2013). Immobili "instabili" nella ricostruzione della capitale. In: Visibileinvisibile : percepire la città tra descrizioni e omissioni. Siracusa: Tyche.

Vecchi, G. (2011). In ricchezza e in povertà : il benessere degli italiani dall'unità a oggi. Bologna: Il Mulino.

Villani, L. (2012). Le borgate del fascismo. Milan: Ledizioni.

Whitehead C. et al. (2011). The Impact of Migration on Access to Housing and the Housing Market. Final Report. LSE, Migration Advisory Committee. 